Chirurgia (2020) 115: 677-680

No. 5, September - October

Copyright@ Celsius

http://dx.doi.org/10.21614/chirurgia.115.5.677

\title{
Late Bowel lischemia and Colovaginal Fistula after Low Anterior Resection in a COVID-19 Patient
}

\author{
Andrea Costanzi ${ }^{1}$, Michela Monteleone ${ }^{1 *}$, Marco Confalonieri', Gaia Colletti ${ }^{1,2}$, Colomba Frattaruolo $0^{1,2}$, \\ Abe Fingerhut ${ }^{3}$
}

${ }^{1}$ General Surgery, San Leopoldo Mandic Hospital, ASST Lecco, Merate, Italy

2University of Milan, General Surgery Residency Program, Milan, Italy

${ }^{3}$ AIMS Academy Clinical Research Unit, Milan, Italy

Department of General Surgery, Ruijin Hospital, Shanghai Jiao Tong University School of Medicine, Shanghai Minimally Invasive

Surgery Center, Shanghai, P. R. China and Section for Surgical Research, Department of Surgery, Medical University of Graz, Austria

*Corresponding author:

Michela Monteleone, MD

San Leopoldo Mandic Hospital

ASST Lecco, Merate, Italy

Largo Leopoldo Mandic 1, 23807

Merate LC

E-mail: m.monteleone@asst-lecco.it

\section{Rezumat}

Ischemie intestinală târzie și fistulă colovaginală după rezecția anterioară joasă în cazul unei paciente diagnosticate cu COVID-19

Răspândirea SARS-CoV-2 în Italia a fost rapidă, cu peste 230.000 de infecții şi 33.000 de decese (31 mai 2020). Impactul COVID-19 asupra intervențiilor chirurgicale este încă necunoscut, efectele sale asupra strategiei de asistență medicală, infrastructurii spitalelor, personalului, economiei regionale şi progresului bolii colorectale, neputând fi evidente decât peste câteva luni. $\mathrm{Nu}$ sunt disponibile rapoarte sistematice despre o incidență mai mare a infectiilor cu COVID-19 la pacienții cu cancer. Cu toate acestea, datele disponibile indică faptul că persoanele în vârstă sunt mai vulnerabile, în special atunci când există comorbidități, cum ar cancerul sau existența unui tratament chimioterapic. Acest articol prezintă cazul unei paciente cu cancer rectal tratat prin tehnica „pull-through”, rezecție rectală anterioară joasă, anastomoză coloanală cu ileostomie de protecție. Pacienta a suferit complicații din cauza infecției Sars-CoV-2 şi a unei colite ischemice târzii (a 31-a zi postoperator) cu fistula colovaginală. Ischemia intestinală târzie este o complicație rară şi poate fi secundară mai multor factori tradiționali, dar cu siguranță trebuie luată în considerare tromboza vaselor mici rezultate în urma bolii Coronavirus.

Cuvinte cheie: Covid-19, SARS-CoV-2, cancer rectal, chirurgie colorectală, ischemie intestinală 


\section{Abstract}

The spread of SARS-CoV-2 in Italy has been rapid, with over 230.000 infections and 33.000 deaths (May 31 ${ }^{\text {st }}, 2020$ ). The full impact of COVID19 on surgery is still unknown, as its effects on healthcare strategy, hospital infrastructure, staff, regional economy and colorectal disease progression, may not be evident before several months. No systematic reports are available about a higher incidence of COVID19 infections in patients with cancer. However, available data indicate that older people are more vulnerable, particularly when there are underlying health conditions such as chemotherapy or active cancer. Herein, we present the case of a patient with rectal cancer treated with pull-through technique low anterior rectal resection and coloanal anastomosis with protective loop ileostomy, complicated with Sars-CoV-2 infection and late (31 post-operative day) colic ischemia with colo-vaginal fistula. Late intestinal ischemia is a rare complication and can be secondary to several traditional factors, but certainly small vessel thrombosis related to Coronavirus disease must be taken into consideration.

Key words: Covid-19, SARS-CoV-2, rectal cancer, colorectal surgery, bowel ischemia

\section{Case Report}

A 62-year old female with low rectal cancer (yPT3N1 (1/18), G2) and no comorbidities, treated with long course neoadjuvant chemoradiotherapy (45Gy + capecitabine) and laparoscopic pull-through low anterior resection, hand-sewn coloanal anastomosis and protective loop ileostomy at the beginning of March, was readmitted to our department 31 day after surgery. Before surgery she underwent a colonoscopy, a thoracic-abdominal CT scan and a pelvic MRI with a good response to the neoadjuvant treatment and no pulmonary findings. We did not perform any preoperative pharyngeal swab for SARS-CoV-2 infection according to the previous internal guidelines of our hospital. The surgical procedure was performed in one stage (length of surgery: 304 minutes), without intraoperative complication (blood loss $<50 \mathrm{ml}$ ). Her post-operative course was complicated by fever $\left(39^{\circ}\right)$ on post-operative day (POD) 2. The patient immediately underwent an abdominal-thoracic CT-scan, endoscopic evaluation of the anastomotic region, and rRT-PCR amplification tests for SARS-CoV-2 infection via two pharyngeal swabs. The CT-scan showed mild bilateral pulmonary "ground-glass" opacities, no signs of pelvic fluid collect or free air at the abdomen; the endoscopic evaluation was unremarkable and both pharyngeal swabs were positive for SARS-CoV-2 infection. In relation to the negative findings of the abdominal CT-scan we decided not to perform a pelvic-MRI. The patient was asymptomatic and did not require supplemental oxygen. She was treated with piperacillin-tazobactam 13.5 gr per day for 10 days, hydroxychloroquine $400 \mathrm{mg}$ per day for 5 days, darunavir/cobicistat 800/150 mg per day for 7 days, lopinavir/ritonavir 200/50 mg 4 administration per day for 7 days and heparin 8.000 UI per day for 10 days and 4.000 UI per day for 6 days after discharge (1). The fever resolution was on POD 10 and the patient was discharged on POD 13 to home quarantine.

The patient was readmitted 31 days after surgery for weight loss and fever $\left(39^{\circ} \mathrm{C}\right)$.

From POD 13 to POD 31 the patient did not showed up to follow-up controls until symptoms worsening: chronic fever, important weight loss and abundant purulent vaginal spotting, because of the lock down status.

Laboratory tests revealed regular D-Dimer and coagulation parameters but elevated C-reactive protein (CRP) $[9 \mathrm{mg} / \mathrm{L}(\mathrm{NV}<1.0)$ and white blood cell count (WBC) $\left(1210^{\wedge} 9 / \mathrm{L}\right.$ (NV 4.0-9.0)]. The rRT-PCR amplification tests for SARS-CoV-2 infection via pharyngeal swab at the readmission was still positive. The 
rectal examination showed a large colovaginal fistula (CVF).

CVF is a rare complication [prevalence 0.9$9.9 \%$ (2)] after low anterior resection for rectal cancer, and its management is difficult. Risk factors for CVF are low anastomosis, preoperative radiotherapy and cancer stage IV (3). Our patient had two of these factors, and in a COVID19-free setting we would not have ascribed the fever to the SARS-CoV-2 infection and we would have intensively investigated the abdomen, perhaps reaching an earlier diagnosis. The abdominal symptoms were mild due to the protective ileostomy and the patient did not show up according to a normal follow-up appointment because of the pandemic. At the time Italy was in 'lockdown' and most outpatient clinics were suspended. The diagnostic delay was probably due to a combination of all these conditions.

Abdominal-thoracic CT-scans performed at the readmission to our department revealed a dilated colic stump and suspected CVF; no new pathological pulmonary findings were found. Bowel ischemia and CVF were confirmed at the endoscopic examination. 31 days after the first surgical approach the patient underwent a laparotomic abdominoperineal resection, ileostomy reversal (end-to-end hand sewn anastomosis), end-colostomy and posterior vaginal wall reconstruction. $15 \mathrm{~cm}$ of ischemic colon proximal to the anastomosis and a large CVF were detected intraoperatively. The length of surgery was 314 minutes, the surgical procedure was uneventful and without intraoperative complications, the patient received blood transfusion due to chronic anemia (blood loss $<100 \mathrm{ml}$ ).

During surgery the highest level of protection was adopted. A designate negativepressure operating room out isolated from the main surgical theaters was settled. The scrub team was equipped with full personal protective equipment (PPE), including disposable FFP2 respirators, double gloves, goggles, visors, caps, shoes and body protection. The number of surgical, nursing, and anesthetist team members was limited to the minimum required to perform the surgery. The use of electrocautery and ultrasonic scalpels was limited to reduce the risk of aerosol viral dispersal and suction devices were intensively used to remove smoke and body fluid and to prevent airborne and aerosol viral transmission.

The postoperative course was slowly favorable, the patient did not require ICU nor assisted ventilation despite pharyngeal swab test for SARS-CoV-2 infection remained positive until discharge on $15^{\text {th }}$ postoperative day. The histologic examination revealed gigantocellular granulomatous inflammation areas, patchy necrosis and hemorrhage (Fig. I). The first faringeal swab tests for SARS-CoV-2 infection became negative 2 months after the diagnosis and the patient is now in good clinical conditions.

\section{Discussion}

This case has important characteristics and consequences:

1. Risk factor analyses for anastomotic leakage after low anterior rectal resection have been widely reported: low anastomosis, preoperative radiotherapy, cancer stage IV, intraoperative bleeding ( $\geq 100 \mathrm{ml})$, tensionreducing suture of anastomosis and asa score (4). Our patient showed two of these factors.

2. The surgical approach strategy for Covid patients in Italy has now changed with protocols involving pharyngeal swabs before hospitalization. In case of a positive result, the patient is admitted to a dedicated ward and treated in an operating room where the highest level of protection is applied.

3. Diagnosis was delayed (one month after the first procedure) and the complication required surgery (Clavien Dindo Classification IIIb). COVID19 co-infection, "lockdown" status and mild symptoms can be implicated as a cause of the diagnostic delay.

4. A recent study (Bhayana $\mathrm{R}$ et al. Radiology 2020) describes that COVID19 related small vessel thrombosis can be a cause of late bowel ischemia. Pathology demonstrated ischemic enteritis with 

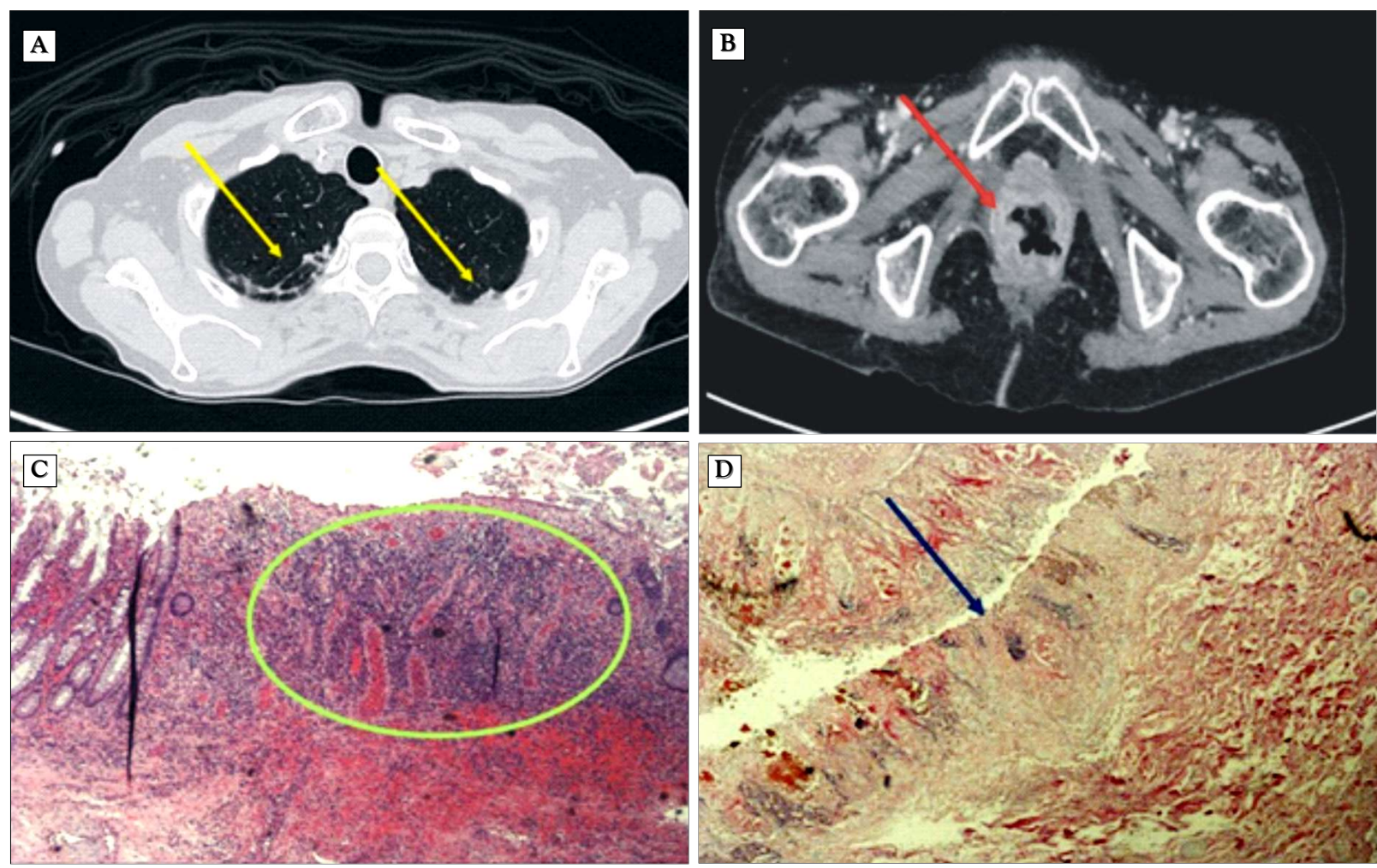

Figure 1. (A) First thorax-CT scan: mild bilateral pulmonary "ground-glass" opacities (yellow arrows). (B) Second abdomen CT-scan: ischemic thickening of the anastomotic wall and colovaginal fistula (red arrow). (C) hematoxylin-eosin: gigantocellular granulomatous inflammation area of the colon (green circle). d. necrotic bowel wall (blue arrow)

patchy necrosis and fibrin thrombi in arterioles (5).

\section{Conclusion}

In conclusion COVID19 influences surgery (service provision, patient care and healthcare strategies) and can be a cause of late bowel ischemia related to small vessel thrombosis in surgical patients. This findings are based on our experience and further studies are needed.

\section{Conflict of Interest / Disclosures}

All authors declare no conflicts of interest.

Funding / Support: none

\section{References}

1. Wright FL, Vogler TO, Moore EE, Moore HB, Wohlauer MV, Urban $\mathrm{S}$, et al. Fibrinolysis Shutdown Correlation With Thromboembolic Events in Severe COVID-19 Infection. J Am Coll Surg. 2020;S10727515(20)30400-2

2. Watanabe J, Ota M, Kawaguchi D, Shima H, Kaida S, Osada S et al. Incidence and Risk Factors for Rectovaginal Fistula After Low Anterior Resection for Rectal Cancer. Int $\mathrm{J}$ Colorectal Dis. 2015;30(12):1659-66

3. Matthiessen P, Hansson L, Sjödah RI, Rutegțrd J. Anastomoticvaginal Fistula (AVF) After Anterior Resection of the Rectum for Cancer-Occurrence and Risk Factors. Colorectal Dis. 2010;12(4): 351-7

4. Kawada K, Sakai Y. Risk Factors for Anastomotic Leakage after Low Anterior Resection. Folia Med (Plovdiv). 2020 Jun 30;62(2):290294.

5. Bhayana R, Som A, Li MD, Carey DF, Anderson MA, Blake MA et al. Abdominal Imaging Findings in COVID-19: Preliminary Observation. Radiology. 2020 May 11;201908 